\title{
KAJIAN MITIGASI BENCANA TANAH LONGSOR DI KABUPATEN
}

\section{BANJARNEGARA}

\author{
Amni Zarkasyi Rahman ${ }^{1}$
}

\begin{abstract}
All disasters experienced by Indonesia in the last years has developed an awareness of the fragility and vulnerability. At this time, the disaster management is currently insufficient anymore. The disaster management gain a new dimension with UU 24/ 2007 and followed some related regulations.

Mitigation program implemented by BPBD Banjarnegara includes Structural and Non Structural Mitigation has been completed well. For example, disaster database, installation of Early Warning System (EWS), information and socialization, training and disaster simulation.

In the future, mitigation will be focused on public education. The government should implement the hazard maps, environmental improvement, evacuation route, installation of low-cost EWS at all location, and relocation. in additon, whole villages must become village disaster response (desa tanggap bencana).
\end{abstract}

Key words : landslides; structural mitigation; non structural mitigation.

\section{PENDAHULUAN}

Potensi bencana alam yang tinggi pada dasarnya tidak lebih dari sekedar refleksi fenomena alam yang secara geografis sangat khas untuk wilayah tanah air kita. Indonesia merupakan negara kepulauan tempat dimana tiga lempeng besar dunia bertemu, yaitu Lempeng Indo-Australia, Lempeng Eurasia, dan Lempeng Pasifik. Interaksi antar lempeng-lempeng tersebut lebih lanjut menempatkan Indonesia sebagai wilayah yang memiliki aktivitas kegunungapian dan kegempaan yang cukup tinggi. Lebih dari itu, proses dinamika lempeng yang cukup intensif juga telah membentuk relief permukaan bumi yang khas dan sangat bervariasi, dari wilayah pegunungan dengan lereng-lerengnya yang curam dan seakan menyiratkan potensi longsor yang tinggi hingga wilayah yang landai sepanjang pantai dengan potensi ancaman banjir, penurunan tanah, dan tsunaminya.

\footnotetext{
${ }^{1}$ Staf Pengajar Program Studi S1 Administrasi Publik FISIP - Undip
} 
Rangkaian bencana yang dialami Indonesia, khususnya pada beberapa tahun terakhir ini, telah mengembangkan kesadaran mengenai kerawanan dan kerentanan masyarakat. Sikap reaktif dan pola penanggulangan bencana yang dilakukan dirasakan tidak lagi memadai. Dirasakan kebutuhan untuk mengembangkan sikap baru yang lebih proaktif, menyeluruh, dan mendasar dalam menyikapi bencana.

Bencana dikelompokkan menjadi tiga jenis, yaitu bencana alam, bencana non alam, dan bencana sosial. Indonesia merupakan negara yang memiliki tiga jenis bencana tersebut. Bencana alam yang terjadi di Indonesia antara lain gempa bumi, tsunami, gunung berapi, pergerakan tanah, banjir, kekeringan, erosi, abrasi, dan cuaca ekstrim serta gelombang ekstrim. Bencana non alam antara lain kegagalan teknologi, epidemi dan wabah penyakit. Sedangkan untuk bencana sosial antara lain adalah konflik sosial dan terorisme.

Pola penanggulangan bencana mendapatkan dimensi baru dengan dikeluarkannya Undang-undang Nomor 24 Tahun 2007 tentang penanggulangan bencana yang diikuti beberapa regulasi yang terkait, yaitu Peraturan Presiden Nomor. 08 Tahun 2008 tentang Badan Nasional Penanggulangan Bencana, Peraturan Pemerintah Nomor 21 Tahun 2008 tentang Penyelenggaraan Penanggulangan Bencana, Peraturan Pemerintah Nomor 22 Tahun 2008 tentang Pendanaan dan Pengelolaan Bantuan Bencana, dan Peraturan Pemerintah Nomor 23 Tahun 2008 tentang Peran Serta Lembaga Internasional dan Lembaga Asing non Pemerintah dalam Penanggulangan Bencana.

Salah satu faktor utama yang menyebabkan adanya peningkatan kerentanan adalah tidak tertib dan tepatnya tata guna lahan. Peningkatan kerentanan ini akan lebih diperparah bila aparat pemerintahan maupun masyarakatnya sama sekali tidak menyadari dan tanggap terhadap adanya potensi bencana alam di daerahnya. Pengalaman memperlihatkan bahwa kejadian-kejadian bencana alam selama ini telah banyak menimbulkan kerugian dan penderitaan yang cukup berat sebagai akibat dari perpaduan bahaya alam 
dan kompleksitas permasalahan lainnya. Sebagai contoh adalah Bencana Tanah Longsor di Dusun Jemblung, Kecamatan Karangkobar Kabupaten Banjarnegara yang menimbulkan banyak korban jiwa.

Banjarnegara adalah Kabupaten yang memiliki kawasan pegunungan dengan resiko tanah longsor cukup tinggi. Pada hari Kamis (11 Desember 2014) dan Jumat (12 Desember 2014), setidaknya terjadi tanah longsor di 25 lokasi meski dalam skala kecil. Bencana tanah longsor terjadi pada hari Jumat malam (12 Desember 2014) di Dusun Jemblung, Kabupaten Banjarnegara (berada di sebuah lembah kecil, dengan perbukitan di belakangnya).

Hujan yang terus turun selama dua hari menyebabkan bukit itu longsor dan menyapu dusun yang berpenduduk lebih dari 300 orang itu. Sekitar 200 orang dapat menyelamatkan diri. Sementara itu, kurang lebih yang tertimbun sekitar 100 orang, 35 rumah yang terdiri dari sekitar 82 kepala keluarga. (http://www.voaindonesia.com/content/satu-dusun-tertimbun-di-banjarnegarajawa-tengah/2557623.html. diakses tanggal 16 Maret 2015 jam 10.00 WIB)

Untuk itu diperlukan upaya-upaya yang komprehensif untuk mengurangi resiko bencana alam, antara lain yaitu dengan melakukan kegiatan mitigasi. Tujuan dari penelitian ini adalah untuk mendiskripsikan upaya mitigasi dan upaya peningkatan mitigasi bencana Tanah Longsor di Kabupaten Banjarnega. METODA PENELITIAN

Penelitian ini merupakan jenis penelitian deskriptif, dengan menggunakan pendekatan Kualitatif dalam menjabarkan mitigasi bencana tanah longsor pada Pemerintah Kabupaten Banjarnegara. Subjek penelitian merupakan individu dan atau kelompok yang diharapkan penulis dapat menceritakan apa yang diketahui tentang sesuatu yang berkaitan dengan fenomena atau kasus yang diteliti. Dalam sebuah penelitian kualitatif subjek penelitian atau narasumber disebut informan. Informan adalah orang yang dapat dimanfaatkan untuk memberikan informasi mengenai situasi dan kondisi latar penelitian. Sehingga informan haruslah seseorang yang mengetahui dan paham tentang materi yang 
dibutuhkan dalam penelitian. Informasi yang didapat dalam penelitian ini dimulai dari pejabat berwenang sampai ke masyarakat.

Penelitian ini akan digunakan teknik purposive sampling yaitu peneliti telah menentukan tempat atau informan yang dituju, dalam penelitian ini adalah Badan Penanggulangan Bencana Daerah Kabupaten Banjarnegara (BPBD Kabupaten Banjarnegara) dan tokoh-tokoh masyarakat di sekitar lokasi rawan/ terdampak bencana longsor di Kabupaten Banjarnegara.

Aspek yang akan diamati dalam penelitian ini adalah strategi mitigasi bencana tanah longsor di Kabupaten Banjarnegara. Adapun yang dimaksud mitigasi adalah sesuai dengan teori mitigasi yang membagi mitigasi menjadi 2 bentuk yaitu:

1. Mitigasi struktural, berupa pembuatan infrastruktur sebagai pendorong minimalisasi dampak dan penggunaan pendekatan teknologi. Gejala yang diamati adalah: penyusunan data base daerah potensi bahaya longsor dan pembuatan early warning system.

2. Mitigasi non struktural, berupa pengelolaan tata ruang dan pelatihan guna meningkatkan kapasitas masyarakat. Gejala yang akan diamati adalah: peningkatan kapasitas masyarakat, melalui : pengetahuan dan sikap, perencanaan kedaruratan dan mobilisasi sumberdaya.

\section{HASIL PENELITIAN}

\section{Mitigasi Struktural Bencana Tanah Longsor}

Mitigasi structural ditujukan dalam rangka pembuatan infrastruktur sebagai upaya minimalisasi dampak dari bencana tanah longsor. Tanah Iongsor atau gerakan tanah merusakkan jalan, pipa dan kabel baik akibat gerakan dibawahnya atau karena penimbunan material hasil Iongsoran. Gerakan tanah yang berjalan lambat menyebabkan penggelembungan (tilting) dan bangunan tidak dapat digunakan. Rekahan pada tanah menyebabkan fondasi bangunan terpisah dan menghancurkan utilitas lainnya didalam tanah. Runtuhan lereng yang tiba-tiba dapat menyeret permukiman turun jauh dibawah lereng. 
Upaya mitigasi struktural yang telah dilakukan oleh Pemebrintah Kabupaten Banjarnegara, dalam hal ini melalui BPBD Kabupaten Banjarnegara diantaranya :

\section{Penyusunan data base daerah potensi bahaya}

Data base daerah potensi bencana merupakan koleksi data-data yang saling berhubungan mengenai suatu potensi kerawanan. Melalui penyusunan data base daerah potensi bahaya longsor. Pada tahun 2015, sebanyak 46 desa/dusun/dukuh dengan total 803 rumah masuk dalam ketegori rawan longsor. Selain itu, terdapat beberapa peta wilayah Kabupaten Banjarnegara dengan fokus wilayah rawan longsor. Peta tersebut termasuk dalam data base yang telah disusun oleh BAPPEDA Kabupaten Banjarnegara. Peta merupakan salah satu bagian terpenting dalam upaya mitigasi structural.

Melihat kondisi Kabupaten Banjarnegara yang sebagian besar wilayahnya rawan terhadap bencana, memang perlu data base yang akurat sehingga masyarakat mengerti dan memahami kondisi lingkungan yang ditinggali. Peta lainnya yang diperlukan sebagai bagian data base penting dalam upaya mitigasi bencana struktural ini adalah peta curah hujan dan peta daerah rawan bencana. Melalui peta ini, BPBD Kabupaten Banjarnegara melakukan upaya mitigasi structural lainnya, yaitu dengan adanya pemasangan alat pendeteksi dini bencana longsor.

\section{Pemasangan Early Warning System (EWS)}

Pemasangan alat peringatan dini (early warning system/EWS) harus terpasang di semua zona yang diindikasikan memiliki kerentanan terhadap bencana alam. Melalui alat ini, warga disekitar lokasi rawan akan mendapat peringatan ketika terjadi pergeseran tanah. Ironisnya saat ini pemasangan EWS di beberapa daerah rawan lonsor hanya sedikit dan terbatas di beberapa lokasi saja.

EWS yang terpasang merupakan EWS sederhana, menggunakan tali nilon yang dikaitkan dengan megaphone dengan harga berkisar Rp300 ribu. Sementara itu, EWS canggih biasanya dilengkapi dengan wirelessekstensometer, 
tiltmeter, penakar hujan, repeater, lampu peringatan, tower antena, dan server lokal serta pemetaan, ditambah denga pelatihan kesiapsiagaan masyarakat lainnya yang membutuhkan biaya banyak kurang lebih Rp300 juta. Cara kerja EWS sederhana ini adalah dengan adanya tali nilon yang dikatikan dalam 2 tiang. Apabila terjadi pergeseran tanah, maka tali nilon akan tertarik sehingga menyebabkan megaphone berbunyi.

EWS merupakan piranti, namun hal yang perlu menjadi fokus utama implementasi EWS dilapangan adalah budaya sadar dari masyarakat dan komitmen pemerintah daerah. Permasalahan dilapangan saat ini adalah adanya penolakan dari masyarakat, karena sering terjadi alarm berbunyi namun tidak terjadi longsor. Sebagai contoh adalah adanya burung yang bertengger di tali nilon yang mengakibatkan tali nilon tertarik sehingga alarm berbunyi. Hal inilah yang menjadi salah satu ketidaknyamanan masyarakat karena menimbulkan kepanikan yang luar biasa dengan adanya pengalaman longsor besar di Dusun Sijemblung yang mengakibatkan satu desa hilang.

Selain EWS sederhana ini, terdapat pula EWS canggih Extensometer yang merupkaan bantuan dari Pemerintah Provinsi Jawa Tengah. Extensometer ini semula niatannya diperuntukan untuk Kabupaten Wonogiri, namun karena potensi longsor di Banjarnegara cukup besar maka alat dipindahkan ke Banjarnegara. Cara kerja Extensometer sedikit berbeda dengan alat canggih EWS yang sebelum ini ada karena hasil pelaporan alat canggih ini dikirimkan dalam bentuk Short Message Sevice (SMS) kepada sejumlah nomor tertentu.

Melalui alat ini, begitu terdapat gerakan atau tanda-tanda gerakan tanah, extensometer secara otomatis akan mengirimkannya kepada nomor penting yang telah dipilih seperti Kepala RT, Kadus, Satgas SAR desa, Camat, kepala BPBD, Komandan SAR Kabupaten, dan Bupati. Karena melalui sarana Handphone maka dimana ada sinyal setiap waktu pesan bisa dikirimkan, sehingga apabila kondisi gerakan tanah masuk tanda bahaya dapat cepat diambil tindakan. 
Akan tetapi, alat ini hanya satu jumlahnya karena nilainya sampai Rp.100 juta. Extensometer ini, merupakan satu-satunya yang dimiliki oleh Balai Penelitian Teknologi Kehutanan Pengelolaan Daerah Aliran Sungai (Balitek DAS) Jawa Tengah. Hingga sampai saat ini di Banjarnegara telah terpasang 5 alat EWS. Kelima alat tersebut terpasang di desa Kertosari, Wanayasa; Kalitlaga, Pagentan; Si Jeruk, Banjarmangu; Pandansari, Wanayasa; dan, Slimpet, Desa Tlaga, Punggelan. EWS Extensometer ini akan dipasang di daerah Slimpet, Tlaga, Punggelan.

\section{Mitigasi Non Struktural Bencana Tanah Longsor}

Mitigasi Non Strktural lebih menekankan kepada peningkatan kapasitas masyarakat. Upaya mitigasi ini dapat dilakukan melalui penyebaran informasi dilakukan antara lain dengan cara: memberikan poster dan leaflet kepada masyarakat yang bermukim yang rawan bencana, tentang tata cara mengenali, mencegah dan penanganan bencana.

\section{Pemberian Informasi}

Pemberian informasi yang sudah dilakukan oleh BPBD Kab. Banjarnegara adalah dengan pemasangan poster bahaya longsor serta tanda daerah rawan longsor. Hal ini dimaksudkan agar setiap masyarakat menyadari bahaya tanah longsor yang sering terjadi.

Pemberian informasi berupa poster atau rambu turut membantu memberikan kesadaran akan pentingnya upaya mitigasi bencana. Poster dan rambu ini perlu diperbanyak dan dipelihara sehingga masyarakat luas, baik yang tinggal di pemukiman rawan maupun tidak mampu secara sadar mengerti tentang bahaya bencana tanah longsor.

\section{Sosialisasi}

Sosialisi secara aktif telah dilakukan oleh BPBD Kabupaten Banjarnegar dibeberapa lokasi tertentu. Diantaranya adalah di wilayah rawan bencana serta di sekolahsekolah. Hal ini bermaksud untuk dapat memberikan kesadaran secara dini kepada masyarakat tentang pentingnya mitigasi bencana. Materi sosialisasi 
yang diberikan diantaranya adalah pengenalan mengenai bencana, upaya mitigasi bencana, dan apa yang dilakukan oleh masyarakat sebelum terjadi bencana, saat terjadi bencana maupun pasca bencana.

Kegiatan sosialisasi secara aktif dilakukan setiap bulan di lokasi yang berbeda-beda, baik itu di wilayah rawan bencana maupun di wilayah non rawan bencana. Sosialisasi yang dilakukan juga melibatkan beberapa stakeholders, diantaranya Kantor Kesatuan Bangsa, Politik dan Perlindungan Masyarakat, Dinas Sosial, Tenaga Kerja dan Transmigrasi, Bagian Kesejahteraan Rakyat, serta dibantu TNI dan Polri.

\section{Pelatihan dan Simulasi Bencana}

Pelatihan kepada masyarakat diperlukan agar masyarakat mengerti dan memahami apa yang harus dilakukan ketika terjadi bencana. Pelatihan yang dilakukan tidak hanya melibatkan masyarakat, namun juga SKPD terkait beserta relawan. Kegiatan utama pada pelatihan yang dilakukan oleh BPBD Kab. Banjarnegara adalah gladi evakuasi atau simulasi bencana.

Gladi evakuasi atau simulasi bencana dibuat untuk lebih mempersiapkan masyarakat kepada kondisi nyata apabila terjadi bencana tanah longsor yang sesungguhnya. Apa yang akan dilakukan, barang-barang apa saja yang akan dibawa dan ke arah mana harus menyelamatkan diri serta siapa yang diselamatkan terlebih dahulu dan lain sebagainya. Simulasi bencana dilakukan untuk lebih kepada mempersiapkan kondisi masyarakat dalam menghadapi bencana dan mengurangi situasi panik sebagai dampak ikutan dari bencana yang dapat menambah jatuhnya korban.

\section{PEMBAHASAN}

\section{Analisa Efektifitas Mitigasi Bencana Tanah Longsor yang sudah dilakukan}

Beberapa hal terkait upaya mitigasi structural maupun non structural masih memiliki beberapa celah yang perlu dilakukan pembenahan. Hal ini dikarenakan rendahnya pemahaman masyarakat sehingga pelru dilakukan mitigasi yang terfokus pada public education yaitu dengan mengadakan sosialisasi dan 
pelatihan tentang bencana alam, perbaikan lingkungan dan jalan yang berfungsi sebagai jalur evakuasi, gladi evakuasi, pembuatan peta rawan bencana, pemasangan alat sistem peringatan dini yang murah dan sederhana serta relokasi.

Pemasangan alat sistem peringatan dini yang merupakan bagian dari mitigasi bencana dilakukan dengan melibatkan masyarakat sehingga akan timbul kepedulian dan rasa memiliki alat yang dipasang, disamping mengetahui sistem kerja dari alat. Sistem peringatan dini gerakan tanah (landslides early warning system) yang dipasang di Desa Sampang yaitu dengan menggabungkan beberapa alat seperti extensometer, alat penakar curah hujan, dan peralatan lainnya yang dihubungkan dengan sirene.

Tujuan utama dipasangnya alat deteksi pergerakan tanah adalah untuk memantau adanya pergerakan tanah hingga batas kondisi kritis sirene berbunyi. Saat sirene (I) berbunyi, berarti hujan kritis terjadi. Kondisi hujan kritis ditentukan berdasarkan angka curah hujan yang telah ditetapkan pada alat yaitu $80 \mathrm{~mm}$ per jam. Sirene (I) dibuat untuk mengkondisikan warga untuk SIAGA (siap evakuasi). Apabila sirene (II) berbunyi, berarti air hujan telah meresap ke dalam tanah dan mengakibatkan retakan tanah melebar hingga mencapai batas kritis yang telah ditetapkan pada alat yaitu $5 \mathrm{~cm}$. Saat sirene (II) berbunyi, maka warga yang sudah SIAGA harus segera meninggalkan lokasi tinggal mereka. Untuk membedakan sumber suara sirene, bunyi sirene (I) dengan bunyi sirene (II) dibuat tidak sama. Dengan sistem peringatan dini ini maka diharapkan lokasi rawan telah bebas dari hunian saat longsor terjadi.

Sosialisasi yang dilakukan harus dilakukan sebelum upaya mitigasi dilaksanakan dengan maksud sebagai pemberitahuan awal kepada masyarakat setempat, sehingga tidak terjadi kesalahfahaman akibat tidak adanya komunikasi. Sosialisasi selanjutnya dilakukan dalam rangka public education yang bertujuan untuk meningkatkan wawasan dan pemahaman masyarakat serta dapat dilakukan dalam berbagai kesempatan baik dalam forum resmi dengan 
melibatkan unsur pemerintah serta pihak terkait lainnya maupun dalam forum tidak resmi seperti dalam perkumpulan masyarakat (seperti dalam acara dakwah dan arisan ibu-ibu), hingga kepada anak-anak sekolah dasar dan juga kepada anak-anak usia dini. Hal inilah yang belum dilakukan oleh BPBD Kab. Banjarnegara.

\section{Upaya Peningkatan Efektifitas Mitigasi Bencana Tanah Longsor}

Menurut Yanuarko, (Profil PUM, Majalah Direktorat Jenderal Pemerintahan Umum, 2007), upaya pengurangan bencana harus ditingkatkan. Konferensi pengurangan risiko bencana sedunia (World Conference for Disaster Reduction/WCDR) di Kobe, Jepang, pada tanggal 18-25 Januari 2005 dan konferensi asia (Asian Conference fot Disaster Reduction/ACDR) di Beijing, China, pada tanggal 27-29 September 2005 tentang pengurangan risiko bencana adalah dasar tekad dan program kerja masyarakat sedunia dalam mengurangi risiko bencana, yang melahirkan Hyogo Framework for Action/HFA (Kerangka Kerja Aksi Hyogo 2005-2015) yaitu membangun ketahanan bangsa dan komunitas terhadap bencana (Building the Resilience of nation and communities to disasters).

Hasil ini memahami bahwa sasaran pembangunan tidak akan tercapai tanpa pertimbangan risiko bencana dan bahwa pembangunan berkelanjutan tidak dapat dicapai kalau pengurangan risiko bencana tidak diarusutamakan kedalam kebijakan, perencanaan dan pelaksanaan pembangunan. Jelasnya, perspektif pengurangan risiko bencana harus dipadukan kedalam perencanaan pembangunan setiap negara dan dalam strategi pelaksanaannya yang terkait. Pada pelaksaannya, hal ini sudah didukung perangkat teknologi yang sudah ada dalam kemampuan untuk mengambil tindakan proaktif untuk mengurangi risiko kerugian akibat bencana sebelum terjadi.

Selanjutnya bencana yang terjadi secara berulang-ulang menjadi suatu antangan bagi pembangunan disetiap negara. Dampak bencana semakin meningkat, bantuan terhadap keadaan darurat juga semakin bertambah, juga 
semakin mengurangi sumber daya untuk biaya pembangunan. Demikian pula secara sosial dan ekonomi, penduduk semakin terpuruk dan terpinggirkan kedalam kemiskinan, ketergantungan akan sumber daya alam akan semakin meningkat, sehingga berdampak pada degradasi lingkungan, yang pada akhirnya semakin meningkatkan kerentanan terhadap risiko bencana. Dengan demikian pengurangan risiko bencana harus menjadi suatu bagian tak terpisahkan dari pembangunan berkelanjutan.

Kerentanan komunitas diawali oleh kondisi-kondisi lingkungan fisik, sosial, dan ekonomi yang tidak aman yang melekat padanya. Kondisi tidak aman tersebut terjadi oleh tekanan-tekanan dinamik, baik internal maupun eksternal. Dinamika-dinamika internal tersebut bukan terjadi dengan sendirinya, tetapi karena terdapat akar permasalahan yang menyertainya, baik secara internal maupun eksternal.

Penanggulangan bencana secara menyeluruh, baik melalui pengurangan dampak maupun menghilangkan penyebab bencana, bukan pekerjaan yang sederhana. Para pelaku perlu melakukan transformasi penanggulangan bencana secara menyeluruh dan sinergis, baik secara structural maupun proses. Individu, keluarga, komunitas dan unit sosial yang lebih tinggi, maupun pemerintah daerah dan pusat perlu melakukan transfor-masi perilaku, kebijakan, hukum dan institusi.

Salah satu paya yang dapat dilakukan adalah upaya menjadikan masyarakat tangguh bencana. Masyarakat yang tangguh bencana ialah masyarakat yang mampu mengantisipasi dan meminimalisir kekuatan yang merusak, melalui adaptasi. Mereka juga mampu mengelola dan menjaga struktur dan fungsi dasar tertentu ketika terjadi bencana. Apabila terkena dampak bencana, mereka akan dengan cepat bisa membangun kehidupannya menjadi normal kembali atau paling tidak dapat dengan cepat memulihkan diri secara mandiri. 
Desa Tangguh merupakan program Nasional/dari BNPB (Perka BNPB 01/2012) dalam rangka mewujudkan Indonesia Tangguh. Program ini merupakan wujud tanggungjawab pemerintah terhadap masyarakatnya dalam hal penanggulangan bencana. Karena masyarakat yang merupakan penerima dampak langsung dari bencana, dan sekaligus sebagai pelaku pertama dan langsung yang akan merespon bencana disekitarnya. Maka masyarakat perlu dibekali dalam konteks pemberdayaan agar menjadi Tangguh, bukan hanya siap menghadapi bencana tapi menjadi TANGGUH.

Masyarakat tangguh adalah mampu mengantisipasi dan meminimalisasi kekuatan yang merusak (ancaman bencana), dengan cara melakukan adaptasi; mampu mengelola dan menjaga stuktur dan fungsi dasar tertentu ketika terjadi bencana; jika terkena dampak bencana, mereka akan dengan cepat bisa membangun kehidupannya menjadi normal kembali. (John Twigg, 2009 dalam http://www.sigana.web.id/index.php/desa tangguh/konsep-desa-tangguh.html diakses tanggal 1 September 2015 jam 20.50 WIB).

Program desa tangguh tanggap bencana, dikhususkan untuk desa yang berpotensi mengalami bencana longsor. Tujuan pembentukan desa tangguh tanggap bencana, untuk menyiapkan masyarakat yang lebih siap menghadapi bencana. Kesiapan itu diwujudkan dalam dokumen penanggulangan bencana yang berlaku hingga 5 tahun.

Terdapat sembilan program yang harus dilakukan oleh setiap desa tangguh tanggap bencana, yakni analisis resiko dengan membuat peta ancaman, kerentanan, dan kapasitas; mendirikan forum relawan; rencana aksi komunitas, rencana kontijensi desa; membuat jalur evakuasi, dan jalur ekonomi untuk pembiayaan pasca bencana.

Desa tangguh bencana saat ini paling tinggi pada level madya, diantaranya Desa Kalitraga, Desa Kertosari, Desa Karangtengah, Desa Tiaga, dan Desa Sijeruk. Selain itu 7 desa lainnya adalah level pratama, yaitu : Desa Dawuhan, Desa Sumberejo, Desa Bakal, desa Nduren, Desa Merden, Desa Karangkobar, 
dan Desa Sampang. Padahal Kabupaten Banjarnegara memiliki 46 desa yang rawan bencana longsor. Hal ini dapat disimpulkan belum setengah dari jumlah desa di Kabupaten Banjarengara rawan longsor telah menjadi Desa Tangguh Bencana.

\section{PENUTUP}

\section{Kesimpulan}

Mitigasi bencana tanah longsor di Kabupaten Banjarnegara dilakukan secara struktural maupun non struktural. Mitigasi structural dilakukan dengan penyusunan data base daerah potensi bahaya dan pemasangan Early Warning System (EWS). Mitigasi non struktural dilakukan dengan pemberian informasi, sosialisasi serta pelatihan dan simulasi bencana.

Upaya yang telah dilakukan untuk meningkatakan efektifitas mitigasi bencana adalah dengan pembentukan masyarakat tangguh serta desa tangguh bencana.

\section{Saran}

1. Perlu diupayakan usaha-usaha meningkatkan kewaspadaan dalam menghadapi bencana dengan mengusahakan adanya pemasangan suatu sistem peringatan dini yang baik, murah dan mudah (low cost early warning system) pada setiap desa/ dusun.

2. Perlu dilakukan usuha-usaha untuk lebih meningkatkan pemahaman masyarakat tentang bencana alam melalui pelatihan dan sosialisasi serta dapat juga dengan memberi pelajaraan dan pengetahuan tentang bencana alam yang diperkenalkan dan ditanamkan sejak usia dini atau dimulai dari usia sekolah dasar.

3. Perlunya peningkatan jumlah desa tanggap bencana sehingga seluruh desa yang berpotensi rawan longsor merupuakan desa tangguh bencana. 


\section{DAFTAR PUSTAKA}

Asriningrum, W. 2003. Indonesia Tidak Punya Peta Rawan Longsor.

Carter, W. Nick. 1991. Disaster Management: A Disaster Manager's Handbook. Manila: Asian Development Bank

Cruden. 1991. A simple definition of landslide. Bulettin Int. Assoc. for Engineering Geology. 43:27-29

Karnawati, D. 2004. Bencana Gerakan Massa Tanah/ Batuan di Indonesia; Evaluasi dan Rekomendasi, Dalam Permasalahan, Kebijakan dan Penanggulangan Bencana Tanah Longsor di Indonesia. P3-TPSLK BPPT dan HSF. Jakarta.

Nurjannah, dkk. 2012. Manajemen Bencana. Bandung: Alfabeta.

Ramli, Soehatman. 2010. Manajemen Bencana. Jakarta: Dian Rakyat.

Sutikno. 1997. Pendekatan Geomorfologi Untuk Mitigasi Bencana Alam Akibat Gerakan Massa Tanah/ Batuan Proceeding Seminar Nasional Mitigasi Bencana Alam UGM, 16-17 September 1994: U53- U65. Yogyakarta: Badan Penerbit Fakultas Geografi UGM.

Smith, K. 2001. Environmental Hazards :Assessing Risk and Reducing Disaster. Routledge. London.

UNDP-UNDRO. 1991. Mitigation strategies in Disaster Mitigation UN Disaster Management Training Program. 